\title{
The Complication of MIPO Technique for Closed Fracture Proximal Third Tibia among Adult Patients
}

Dr. A.T. M. Rezaul Karim ${ }^{1}$, Dr. A. K. M. Harun-Ar-Rashid ${ }^{2}$, Dr. Mohammad Shaha Alam ${ }^{3}$, Dr. Ayesha Begum ${ }^{4}$, Dr. Abdur Rahman ${ }^{5}$, Dr. A. H. M. Azgar Ali Chowdhury ${ }^{6}$

\footnotetext{
${ }^{1}$ Consultant of Orthopedic Surgery, Parkview Hospital, Chattogram, Bangladesh

${ }^{2}$ Assistant Prof. of Orthopedic Surgery, Cox's Bazar Medical College, Cox's Bazar, Bangladesh

${ }^{3}$ Assistant Prof. of Surgery, Cox’s Bazar Medical College, Cox's Bazar, Bangladesh

${ }^{4}$ Assistant Prof. of Pediatrics, Chattogram Medical College, Chattogram, Bangladesh

${ }^{5}$ Assistant Prof. of Orthopedic Surgery, Chattogram Medical College, Chattogram, Bangladesh

${ }^{6}$ Junior Consultant of Orthopedic Surgery, Chattogram Medical College Hospital, Chattogram, Bangladesh
}

Objective: In this study our main goal is to evaluate the complication of MIPO technique for closed fracture proximal third tibia among adult patients. Method: This observational study was carried out at Department of Orthopaedic Surgery, Chattogram Medical College Hospital; Chattogram, From January 2012 to June 2013. A total of 26 patients within 18-60 years of age and were admitted in different Orthopaedic units of Chattogram Medical College Hospital with closed fracture in proximal tibia were included in the study. Results: During the study, motor vehicle accident accounted for 10 cases $(43.48 \%)$, pedestrian struck by a motor vehicle for 3 cases (13.04\%). Work accidents were responsible for 04 fractures $(17.39 \%)$, mostly because of a falling heavy object. 3 fractures $(13.04 \%)$ were caused by high-energy fall from heights of at least 3 meters. Sports injuries caused fractures in 2 patients $(8.69 \%)$, of them 2 had football injuries. Direct trauma by h/o Assault for 1 cases (4.35\%). Collectively, low-energy mechanisms had a mean time to union of 19.0 weeks. On the other hand, high-energy injuries had a mean time to union of 22.34 weeks with 3 delayed unions. intraoperative displacement of a wedge fragment or comminution during plate positioning, occurred in four cases followed by the development of impending compartment syndrome after locking plate fixation occurred in only one patient, early aseptic wound complications including dehiscence, edge necrosis and haematoma formation occurred in three patients $(13.04 \%$ ), superficial infection (wound or soft tissue infection superficial to the deep fascia without muscle or bone involvement and with stable implant) occurred in 2 cases. Conclusion: Most importantly, it was easy to use, it was biological in the sense that the blood circulation to the proximal tibia was not compromised, the plate had not need to be configured and the angular screw fixation ensures fixed-angle stabilization. So, locking compression plate fixation in minimal invasion plate osteosynthesis (MIPO) is a reliable method of treatment of proximal tibial fracture without any significant problem.

Keywords: closed fracture proximal third of tibia, MIPO technique, locking plate.

Copyright $\left({ }_{0} 2021\right.$ The Author(s): This is an open-access article distributed under the terms of the Creative Commons Attribution 4.0 International License (CC BY-NC 4.0) which permits unrestricted use, distribution, and reproduction in any medium for non-commercial use provided the original author and source are credited.

\section{INTRODUCTION}

Proximal third tibia fracture especially comminuted fractures are difficult to treat in all over the world. Fixation of diaphyseal fracture by intramedullary nail remains the gold standard but it is generally considered unsuitable for unstable proximal third of tibial fracture due to technical difficulty and design limitation $[1,2]$.

In most of the cases we use open technique for reduction which needs extensive surgical approach. It jeopardized vascularity in the fracture site and increasing the chance of infection, delayed union, nonunion. DCP needs direct anatomical reduction and there is movement at screw plate interface. In comminuted fracture needs no attempt to reduce the fracture anatomically only length, alignment and rotation to be maintained, insertion of screws proximal and distal to it. So, no disturbance of biological internal environment occurs [3, 4].

There are three technique of use of LCP open, MIPO and LISS technique by bridging the 
fracture. Open technique may increase the rate of nonunion. MIPO and LISS technique demands extra instrument set (Zig system). But bridge plating could be done without disturbing the fracture haematoma and extra instrument. One or two snaps of portable X-rays may be enough during operation [5].

In this study our main goal is to evaluate the complication of MIPO technique for closed fracture proximal third tibia among adult patients.

\section{OBJECTIVE}

- To assess the complication of MIPO technique for closed fracture proximal third tibia among adult patients.

\section{Methodology}

Type of study: This was an observational study.

Place and period of study: This study was carried out at Department of Orthopedic Surgery, Chattogram Medical College Hospital; Chattogram, From January 2012 to June 2013.

Study population: All the patients were within 18-60 years of age and were admitted in different orthopedic units of Chattogram Medical College Hospital with closed fracture in proximal tibia. For diagnosis AO classification of proximal metaphyseal and proximal shaft fracture of tibia was used. Cases were selected purposively.

Sample size: Total 26 patients were enrolled in the study. Three patients were lost to follow-up. So, finally 23 patients were available for evaluation.

\section{Inclusion Criteria}

- Age - 18-60 years

- Sex - patients were selected irrespective of sex.

- Site - Fractures of the proximal metaphysis and proximal diaphyseal fracture of tibia.

- Closed fracture.

- Those fractures in which initial conservative management for soft tissue injury.

- Within 2 weeks of initial injury.

\section{Exclusion Criteria}

- It excludes patients of age less than 18 years and more than 60 years.

- Type of fracture

- Open fracture

- Diaphyseal fractures extending into middle and distal third.

- Fracture associated with neuro-vascular injury.

- Pathological fractures.

\section{Preoperative preparation}

Patient was consulted regarding the treatment procedure with emphasis on the available treatment options along with merits and demerits of each. He/she was also being informed about the possible postoperative sequels. Informed written consent was obtained from each case included in the study. All issues regarding the patients' welfare were approved by the local ethical committee.

\section{Data Analysis}

Collected data were analysed using software SPSS (Statistical Package for Social Sciences) version 23 for windows. Descriptive and inferential statistics were used to analyse the data. Analysed data were presented in the form of tables and charts with due interpretation.

\section{RESULTS}

In table-1 shows age distribution of the patients. The study population included 23 patients, who ranged in age between 18 years and 60 years (average 35.43 years). The mean age for males was 36.35 years whereas the mean age for females was 32.83 years. The maximum incidence occurred between 21 and 40 years with $78 \%$ of cases occurring in patients before their fifth decade. The following table is given below in detail:

Table-1: Age distribution of the patients $(n=23)$

\begin{tabular}{|l|l|l|l|}
\hline Age (Yrs) & Frequency & Percentage & Mean age \\
\hline $16-20$ & 0 & $0 \%$ & \multirow{3}{*}{35.43} \\
\cline { 1 - 3 } $21-30$ & 7 & $30.43 \%$ & \\
\hline $31-40$ & 11 & $47.83 \%$ & \\
\hline $41-50$ & 3 & $13.04 \%$ & \\
\hline $51-60$ & 2 & $08.70 \%$ & \\
\cline { 1 - 2 } & &
\end{tabular}

In table-2 shows sex Distribution. Most $(73.91 \%)$ of the patients were male and the rest $(26.09 \%)$ were female, giving a male to female ratio of roughly 4:1. The following table is given below in detail:

Table-2: Sex distribution

\begin{tabular}{|l|l|l|l|}
\hline Sex & Males & Females & Total \\
\hline All patients of the study & 17 & 06 & 23 \\
\hline Percentage & $73.91 \%$ & $26.09 \%$ & $100 \%$ \\
\hline
\end{tabular}

In figure-1 shows mode of injury where motor vehicle accident accounted for 10 cases (43.48\%), pedestrian struck by a motor vehicle for 3 cases (13.04\%). Work accidents were responsible for 04 fractures $(17.39 \%)$, mostly because of a falling heavy object. 3 fractures (13.04\%) were caused by highenergy fall from heights of at least 3 meters. Sports injuries caused fractures in 2 patients $(8.69 \%)$, of them 2 had football injuries. Direct trauma by h/o Assault for 1 cases $(4.35 \%)$. The following figure is given below in detail: 


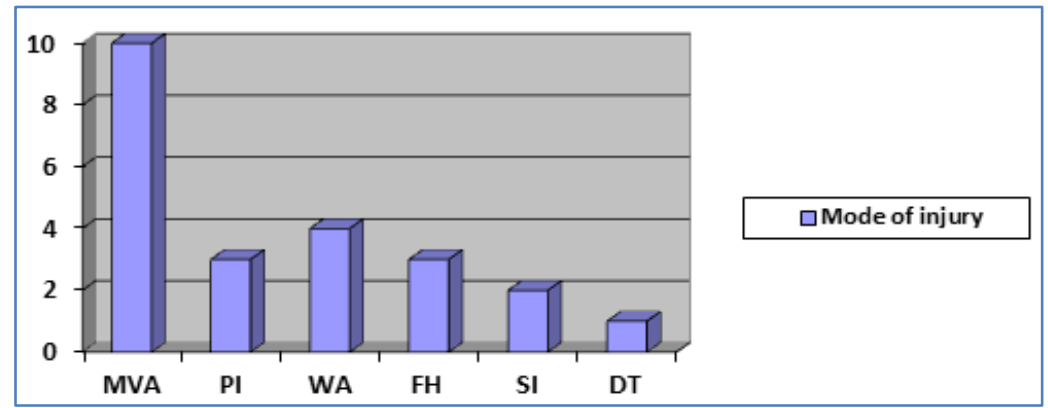

Fig-1: Mode of injury

In table-3 shows mechanism of trauma. Collectively, low-energy mechanisms had a mean time to union of 19.0 weeks. On the other hand, high-energy injuries had a mean time to union of 22.34 weeks with 3 delayed unions. The following figure is given below in detail:

Table-3: Fracture union according to the mechanism of injury

\begin{tabular}{|l|l|l|l|}
\hline & Union & Delayed union & Non union \\
\hline High energy trauma & 22.34 weeks & 3 & 0 \\
\hline Low energy trauma & 19.0 weeks & 0 & 0 \\
\hline
\end{tabular}

In table-4 shows complication of the patients where intraoperative displacement of a wedge fragment or comminution during plate positioning, occurred in four cases followed by the development of impending compartment syndrome after locking plate fixation occurred in only one patient, early aseptic wound complications including dehiscence, edge necrosis and haematoma formation occurred in three patients $(13.04 \%)$, superficial infection (wound or soft tissue infection superficial to the deep fascia without muscle or bone involvement and with stable implant) occurred in 2 cases. The following table is given below in detail:

Table-4: Complication of the patients

\begin{tabular}{|l|l|}
\hline Complication & n \\
\hline Early technical complications & 4 \\
\hline Compartment Syndrome & 1 \\
\hline Neurological injury & 0 \\
\hline Wound problems & 3 \\
\hline Superficial infection & 2 \\
\hline
\end{tabular}

In table-5 shows distribution of the patients according to Varus/Valgus Angulati where 1 cases $(4.35 \%)$ had $5^{\circ}-7.5^{\circ}$ valgus angulation. The following table is given below in detail:

Table-5

\begin{tabular}{|l|l|l|}
\hline $\begin{array}{l}\text { Valgus Mal } \\
\text { Union }\end{array}$ & $\begin{array}{l}\text { Valgus Mal } \\
\text { Union }\end{array}$ & Percentage \\
\hline $5-7.5^{\circ}$ & $5-7.5^{\circ}$ & 4.35 \\
\hline $7.5^{\circ}-10 \mathrm{o}$ & $7.5^{\circ}-10 \mathrm{o}$ & - \\
\hline$>10 \mathrm{o}$ & $>10 \mathrm{o}$ & - \\
\hline & $>\mathbf{1 0}^{\circ}$ & \\
\hline
\end{tabular}

\section{DISCUSSION}

Dominant right sides due to searching of support during high energy trauma. The cause of left side involvement is probably due to unpreparedness following high velocity injury in most of the cases [6].

High energy trauma following road traffic accident occurs most commonly in young active people. The principal earning member of the family usually is working outside and more prone to road traffic accident.

Average healing rate was 21.6 weeks. In this study all fractures were united. 3(13.04) patients developed delayed union which healed without the need of bone graft. There was no nonunion. In one study treated 29 patients out of them 24 patients healed within 6 months \& 3 developed delayed unions [7]. Another study treated 21 patients of them 17 fracture healed within 6 months and 2 developed delayed union and two patient developed nonunion [8].

In this study 5 patients (21.74) noticed knee pain during walking. Most of the patient had no knee \& ankle stiffness. In the study eight patients out of 19 had limp due to one patient need stick as a walking support. Four patients of them reduce movement then 20 degree compare to contralateral side [9]. In another study out of 22 patients one patient presented with persistant pain at distal end of scar [10].

In the study one patient valgus maluunion $\left(7^{\circ}\right)$; who also developed $<1 \mathrm{~cm}$ leg length discrepancy. No patient had delayed infection or delayed wound breakdown. Only one patient developed surface wound infection 1 month after surgery which successfully treated by oral antibiotics. In other study, found out of 29, 4 had angular deformities one had varus deformity 
$\&$ three patient had a valgus deformity. No patients had a leg-length discrepancy greater than $1.0 \mathrm{~cm}$ [11].

In another study wound breakdown in two cases \& superficial wound infection in one case [12]. In another study one had superficial infection on lateral side that was treated without problem by antibiotics [13].

\section{Conclusion}

Most importantly, it was easy to use, it was biological in the sense that the blood circulation to the proximal tibia was not compromised, the plate had not need to be configured and the angular screw fixation ensures a fixed-angle stabilization. So, locking compression plate fixation in minimal invasion plate osteosynthesis (MIPO) is a reliable method of treatment of proximal tibial fracture without any significant problem.

\section{REFERENCE}

1. Hazarika S, Chakravarthy J, Cooper J. Minimally invasive locking plate osteosynthesis for fractures of the distal tibia-results in 20 patients. Injury. 2006 Sep 1;37(9):877-87.

2. Sarmiento A, Latta LL. 450 closed fractures of the distal third of the tibia treated with a functional brace. Clinical Orthopaedics and Related Research®. 2004 Nov 1;428:261-71.

3. Bedi A, Le TT, Karunakar MA. Surgical treatment of nonarticular distal tibia fractures. JAAOSJournal of the American Academy of Orthopaedic Surgeons. 2006 Jul 1;14(7):406-16.

4. Anglen JO. Early outcome of hybrid external fixation for fracture of the distal tibia. Journal of Orthopaedic Trauma 1999; 13(2):92-7.
5. Blachut PA, O'brien PJ, Meek R, Broekhuyse HM. Interlocking intramedullary nailing with and without reaming for the treatment of closed fractures of the tibial shaft. A prospective, randomized study. JBJS. 1997 May 1;79(5):640.

6. Drosos G, Karnezis IA, Bishay M, Miles AW. Initial rotational stability of distal tibial fractures nailed without proximal locking: the importance of fracture type and degree of cortical contact. Injury. 2001 Mar 1;32(2):137-43.

7. Kneifel T, Buckley R. A comparison of one versus two distal locking screws in tibial fractures treated with unreamed tibial nails: a prospective randomized clinical trial. Injury. 1996 May 1;27(4):271-3.

8. Fan CY, Chiang CC, Chuang TY, Chiu FY, Chen TH. Interlocking nails for displaced metaphyseal fractures of the distal tibia. Injury. 2005 May 1;36(5):669-74.

9. Janssen KW, Biert J, van Kampen A. Treatment of distal tibial fractures: plate versus nail. International orthopaedics. 2007 Oct;31(5):709-14.

10. Sommer C, Gautier E, Müller M, Helfet DL, Wagner M. First clinical results of the Locking Compression Plate (LCP). Injury. 2003 Nov 1; 34:B43-54.

11. Rüedi TP, Buckley RE, Moran CG. AO philosophy and evolution. $2^{\text {nd }}$ edi New York: Georg Thieme Verlag. 2007: 6 .

12. DeBastiani G, Aldegheri R, and Renzi Brivio L. "The treatment of fractures with a dynamic axial fixator". J Bone Joint Surg. 1984; 66:538-46.

13. Babst R, Bavonratanavech S, Pesantez R. Minimally Invasive Plate Osteosynthesis. $2^{\text {nd }}$ ed. Davos (Switzerland): Thieme Medical and Scientific Publishers Private Ltd. 2012: 8. 